\title{
Effect of different doses of herbicides on yield attributes and grain yield of dry seeded rice (Oryza sativa L.)
}

\author{
Fayaz Ahmed Bahar and Zahida Rashid*
}

Department of Agronomy, G. B. Pant University of Agriculture and Technology, Pantnager-263145 (Uttaranchal), India.

Accepted 27 August, 2013

\begin{abstract}
A field experiment was conducted during kharif season of 2002 to find out the effective dose and stage of application of cyhalofopbutyl at 80,100 and $120 \mathrm{~g} \mathrm{ha}^{-1}$, quinclorac at $125,187.5$ and $250 \mathrm{~g} \mathrm{ha}^{-1}$, clefoxydim at 50,75 and $100 \mathrm{~g} \mathrm{ha}^{-1}$ applied at 15 DAS and pretilachlor at $0.5,0.75$ and $1.0 \mathrm{~kg} \mathrm{ha}^{-1}$, pendimethalin at $1.0 \mathrm{~kg} \mathrm{ha}^{-1}$ applied as pre-emergence for studying their effect on yield attributes and grain yield of dry seeded rice (Oryza sativa L.). Highest yield attributes and grain yield $\left(62.8 \mathrm{q} \mathrm{ha}^{-1}\right)$ were observed under weed free condition followed by pendimethalin at $1.0 \mathrm{Kg} \mathrm{ha}^{-1}\left(54.0 \mathrm{q} \mathrm{ha}^{-1}\right)$. The lowest grain yield $\left(0.85 \mathrm{q} \mathrm{ha}^{-1}\right)$ was recorded in weedy check. Higher doses of cyhalofopbutyl, quinclorac, clefoxydim and pretilachlor recorded significantly higher yield attributes and grain yield than their respective lower doses. Uncontrolled weed growth caused $98.64 \%$ reduction in grain yield of rice. None of the treatments could produce grain yield at par with weed free treatment and pendimethalin at $1.0 \mathrm{Kg}$ $\mathrm{ha}^{-1}$ proved to be more promising than all other herbicides.
\end{abstract}

Key words: Dry seed, herbicide, rice, weed.

\section{INTRODUCTION}

Weed infestation in dry seeded rice (Oryza sativa L.) is one of the major constraints responsible for low yield and the depression of yield due to weed competition may be as high as 40 to $100 \%$ (Choubey et al., 2001) depending upon the intensity and type of weed flora. Prolonged use of herbicides with same mode of action can result in development of herbicide resistance in weeds (Malik and Singh, 1995). Repeated use of any single herbicide in a crop also generates a shift in the composition of weed flora with the result that secondary weeds may become of primary concern. In view of the above facts, the present investigation was undertaken to find out the effective dose and stage of application of herbicides.

\section{MATERIALS AND METHODS}

A field expression was conducted in the D2 block at Crop Research
Center, GBPUA \& T, Pantnagar, district U.S. Nagar, Uttaranchal, during kharif season of 2002. The soil of the experimental site was loam in texture with $\mathrm{pH}$ 7.6. The treatments consisted of cyhalofopbutyl at $80,100,120 \mathrm{~g} \mathrm{ha}^{-1}$, quinclorac at 125, 187.5, 250 $\mathrm{g} \mathrm{ha}^{-1}$, clefoxydim at $50,75,100 \mathrm{~g} \mathrm{ha}^{-1}$, all applied at $15 \mathrm{DAS}$; pretilachlor at $0.5,0.75,1.0 \mathrm{Kg} \mathrm{ha}^{-1}$ and pendimethalin at $1.0 \mathrm{Kg} \mathrm{ha}$ ,both applied at 2 DAS, compared with weedy and weed-free checks. The experiment was laid out in randomized block design replicated three times. Herbicides were applied at spray volume of $6001 \mathrm{ha}^{-1}$. Rice variety Sarjoo-52 at $50 \mathrm{Kg}$ seed ha ${ }^{-1}$ was sown in rows $20 \mathrm{~cm}$ apart during the third week of June.

\section{RESULTS AND DISCUSSION}

All the treatments gave significantly higher grain yield then weedy check except clefoxydim at $50 \mathrm{~g} \mathrm{ha}^{-1}$. The highest grain yield $\left(62.81 \mathrm{q} \mathrm{ha}^{-1}\right)$ was recorded in weed free treatment followed by pendimethalin at $1.0 \mathrm{~kg} \mathrm{ha}^{-1}$ 
Table 1. Effect of treatments on the yield attributes and grain yield of rice.

\begin{tabular}{|c|c|c|c|c|c|c|c|c|}
\hline Treatment & $\begin{array}{l}\text { Dose } \\
\left(\mathrm{g} \mathrm{ha}^{-1}\right)\end{array}$ & $\begin{array}{c}\text { No.of panicles } \\
\left(\mathrm{m}^{-2}\right)\end{array}$ & $\begin{array}{l}\text { No.of grains } \\
\text { panicle }^{-1}\end{array}$ & $\begin{array}{l}\text { 1000-grain } \\
\text { weight }(g)\end{array}$ & $\begin{array}{l}\text { Grain yield } \\
\left(q \text { ha }^{-1}\right)\end{array}$ & $\begin{array}{c}\text { Straw yield } \\
\left(q \mathrm{ha}^{-1}\right)\end{array}$ & $\begin{array}{l}\text { Grain/straw } \\
\text { ratio }\end{array}$ & $\begin{array}{c}\text { Crop weed } \\
\text { competition } \\
\text { index(WI) }\end{array}$ \\
\hline Cyhalofopbutyl & 80 & 168 & 85 & 22.36 & 12.3 & 35.6 & 0.34 & 80.5 \\
\hline Cyhalofopbutyl & 100 & 238 & 108 & 22.86 & 17.1 & 57.3 & 0.29 & 72.6 \\
\hline Cyhalofopbutyl & 120 & 299 & 131 & 22.90 & 35.1 & 75.3 & 0.46 & 44.2 \\
\hline Quinclorac & 125 & 231 & 104 & 22.40 & 8.9 & 24.6 & 0.35 & 85.7 \\
\hline Quinclorac & 187.5 & 235 & 107 & 22.70 & 23.3 & 70.5 & 0.32 & 62.8 \\
\hline Quinclorac & 250 & 263 & 114 & 22.78 & 31.6 & 78.1 & 0.39 & 49.7 \\
\hline Clefoxydim & 50 & 145 & 76 & 22.56 & 8.3 & 24.8 & 0.33 & 86.8 \\
\hline Clefoxydim & 75 & 209 & 86 & 22.75 & 8.7 & 33.0 & 0.26 & 86.1 \\
\hline Clefoxydim & 100 & 242 & 107 & 22.76 & 23.3 & 66.8 & 0.34 & 63.0 \\
\hline Pretilachlor & 500 & 253 & 106 & 22.83 & 22.4 & 52.0 & 0.42 & 64.4 \\
\hline Pretilachlor & 750 & 252 & 115 & 22.90 & 23.6 & 56.6 & 0.41 & 62.4 \\
\hline Pretilachlor & 1000 & 265 & 122 & 23.03 & 31.3 & 73.7 & 0.42 & 49.8 \\
\hline Pendimethalin & 1000 & 310 & 143 & 23.53 & 54.0 & 116.9 & 0.46 & 13.7 \\
\hline Weed free & - & 325 & 146 & 22.73 & 62.8 & 125.0 & 0.50 & 0.00 \\
\hline Weedy check & - & 102 & 73 & 21.73 & 0.85 & 9.1 & 0.09 & 98.6 \\
\hline C.D at $5 \%$ & - & 29 & 17 & 1.1 & 7.50 & 15.20 & 0.07 & 4.2 \\
\hline
\end{tabular}

$\left(54.0 \mathrm{q} \mathrm{ha}^{-1}\right)$ which was significantly lower than weed free. The lowest grain yield $\left(0.85 \mathrm{q} \mathrm{ha}^{-1}\right)$ was recorded in weedy check. Uncontrolled weed growth caused $98.6 \%$ reduction in grain yield of rice. Similar findings have also been reported by Kolhe and Tripathi (1998) and Choubey et al. (2001). In weed free treatment, the highest number of panicles $\left(325 \mathrm{~m}^{-2}\right)$, number of grain per panicle (146) and 1000 grain weight $(23.73 \mathrm{~g})$ were recorded. However, all these yield components were significantly reduced in weedy check. The decrease in yield components in weedy treatment and increase in yield attributes in weed free and pendimethalin at $1.0 \mathrm{Kg} \mathrm{ha}^{-1}$ may be attributed to the more crop weed competition in weedy check and very low degree of crop weed competition in other two treatments (Table 1). The highest grain yield in weed free treatment has also been reported by Singh et al. (2003).

Cyhalofopbutyl at $120 \mathrm{~g} \mathrm{ha}^{-1}$ and clefoxydim at $100 \mathrm{~g} \mathrm{ha}^{-1}$ produced significantly more grain yield than cyhalofopbutyl at $80,100 \mathrm{~g} \mathrm{ha}^{-1}$ and clefoxydim at 50 and $75 \mathrm{~g} \mathrm{ha}^{-1}$. Pretilachlor at 1.0 $\mathrm{kg} \mathrm{ha}^{-1}$ gave significantly higher grain yield than pendimethalin at $1.0 \mathrm{Kg} \mathrm{ha}^{-1}$ and weed free treatment. This was because of the toxicity of these treatments on the crop and is evident from the less number of panicles per square metre and less number of grains per panicle (Table 1). Quinclorac at $125 \mathrm{~g} \mathrm{ha}^{-1}$ gave significantly lower grain yield than quinclorac at 187.5 and $250 \mathrm{~g}$ ha

? This was due to the high degree of crop weed competition, less number of grains per panicle and 1000-grain weight in former than in latter treatments. Similar findings have also been reported by Bahar and Singh (2004).
The highest grain/straw ratio in weed free treatment was associated with the highest grain yield as well as highest straw yield. Pendimethalin at $1.0 \mathrm{~kg} \mathrm{ha}^{-1}$ and cyhalofopbutyl at $120 \mathrm{~g} \mathrm{ha}^{-1}$ give grain straw ratio at par with the weed free treatment though grain yield in these two treatments were significantly lower than that of weed free treatment. Thus it can be concluded that pendimethalin at $1.0 \mathrm{~kg} \mathrm{ha}^{-1}$ proved to be more promising than all other herbicides though none of the treatments could produce grain yield at par with weed free treatment.

\section{REFERENCES}

Bahar FA, Singh G (2004). Effect of herbicides on dry seeded rice (Oryza sativa L.) and associated weeds. Indian J. Weed Sci. 36(3,4):269-270. 
Choubey NK, Kolhe SS, Tripathi RS (2001). Relative performance of cyhalofopbutyl for weed control in direct seeded rice. Indian J. Weed Sci. 2.33(3,4):132-135.

Kolhe SS, Tripathi RS (1998). Integrated Weed ManagementIn direct seeded rice. Indian J. Weed Sci. 30(1,2):51-53.

Malik RK, Singh S (1995). Littleseed canary grass (phalaris minor) resistance of isoproturon in India. Weed Technol. 9:419-425.
Singh GV, Singh $P$, Singh $Y$, Singh KM, Mortimer M, Johnson DE, White JL (2003). Efficacy of herbicides alone and in combinations in direct seeded rice. Biennial Conference ISWS, March 12-14, GBPUA \& T, Pantnagar, P. 3. 